\title{
Ways to Enhance the Competitiveness of Russia in an Unstable World Economy
}

\author{
Mechtcheriakova Svetlana Anatolievna ${ }^{1}$, Gurianov Igor Nikolaevich ${ }^{2} \&$ Gurianova Elina Anatolievna $^{1}$ \\ ${ }^{1}$ Department of General Management, Kazan Federal University, Kazan, Russian Federation \\ ${ }^{2}$ Securities department, OAO “Tatneftekhiminvest-holding”, Kazan, Russian Federation \\ Correspondence: Mechtcheriakova Svetlana Anatolievna, Department of General Management, Kazan Federal \\ University, Kazan, Russian Federation. E-mail: s-lanaM@mail.ru
}

\author{
Received: August 23, 2014 Accepted: September 6, 2014 Online Published: November 27, 2014 \\ doi:10.5539/ass.v10n24p185 URL: http://dx.doi.org/10.5539/ass.v10n24p185
}

\begin{abstract}
Despite the recent positive trends in the Russian economy, the problem of increasing national competitiveness today. With the acceleration of globalization of economic relations and deepening of the international division of labour, a priority is to ensure an adequate level of competitiveness of the Russian economy. The dynamics of trends of the economic situation (world and Russian) reiterates the need to continue the implementation of institutional reforms in the country, the establishment of a new system of socio-economic relations, development of market mechanisms for deepening mutually beneficial cooperation with foreign States. For the formation of new conditions for sustainable development of the world economy should be significant structural changes in the technological and organizational nature, both at the international and at the national level. The high level of uncertainty in the economy of modern Russia leads to two main outcomes are poor risks and inadequate care, business people and organizations in investment activity, which ultimately leads to a decrease in their competitiveness. The risks are increased when growing uncertainty, instability, take place reform or undergoing rapid spontaneous changes in the economy. The phenomenon of growing uncertainty in the transformed economy not sufficiently researched. The main objective of the study was the development of the main directions of improving global competitiveness. The article presents the results of the analysis of competitive advantages and disadvantages of Russia in the world economy. Also examined the major factors contributing to or impeding to increased rating of the world competitiveness in the future. Based on this an attempt was made to develop basic strategic directions of increasing international competitiveness of Russia.
\end{abstract}

Keywords: competitiveness, competitive advantage, the global competitiveness index

\section{Introduction}

With the acceleration of globalization of economic relations and deepening of the international division of labour, a priority is to ensure an adequate level of competitiveness of the Russian economy. The dynamics of trends of the economic situation (world and Russian) reiterates the need to continue the implementation of institutional reforms in the country, the establishment of a new system of socio-economic relations, development of market mechanisms for deepening mutually beneficial cooperation with foreign States.

The high level of uncertainty in the economy of modern Russia leads to two main outcomes are inadequate risks and inadequate care, business people and organizations in investment activity, which ultimately leads to a decrease in their competitiveness. The risks are increased when are growing up uncertainty, instability, too fast reforms were carried out or were undergone rapid spontaneous changes in the economy. The phenomenon of growing of economic uncertainty in the transformed economy not has been researched. Theoretical analysis of the competitiveness of the economy presented in the studies of some foreign scientists (Heckscher, 1919; Ohlin, 1933; Porter, 1990; Cooper, 2004; Heyne, 1973; Kaufmann, 2001; De Grauwe, 2013; Huggins, 2011; Romer, 1990). In modern economic literature questions competitiveness of national economies in a globalizing developed in research Russian and foreign scientists (Stiglitz, 2003; Castells, 1994; Lambin, 1996; Myrdal, 1957; Noonan, 2008; Jones, 1999; Miozzo, 2007).

Identify macroeconomic constraints that affect national competitiveness, as well as certain aspects of Russian economic policy in terms of its integration into the world economy were devoted works such modern Russians 
researchers (Andrianov, 1998; Kirshin, 2014; Kramin, 2014; Safiullin, 2014; Hajrullina, 2014; Validova, 2014). Selected issues of international competitiveness and key linkages were reflected in the works of a number of foreign specialists (Balassa, 1961; Krugman, 1995; Ohlin, 1933; Sachs, 1995; Stiglitz, 2003; Heckscher, 1919). The necessary material for the study were the conclusions and the provisions contained in the works and reviews of international organizations such as IMF, the World Bank, WEF, as well as statistical base of these organizations.

\section{Methodology}

\subsection{Design}

This work is based on the methodology used by the World Economic Forum. The modern methodology of the World economic forum allocates two parties of concept of the international competitiveness. The first is an ability of economy to reach constant economic growth during the intermediate term and long-term period. It is based on understanding economists a determinant of complex process of economic growth and development. The second is a development of the factors specific to the companies promoting increase of efficiency and productivity at micro level. The world economic forum defines national competitiveness as ability of the country and its institutes to provide stable rates of economic growth which would be steady in intermediate term prospect The countries with high indicators of national competitiveness, as a rule, provide higher standard of well-being of the citizens. It is supposed that the given Index should be used by the states which aspire to liquidation of obstacles in a way of economic development and competitiveness, as the tool for the analysis of problem points in their economic policy and workings out of strategy on achievement of steady economic progress.

Representatives of the World economic forum specify that competitiveness of national economies is defined by numerous and rather versatile factors. On state of the economy negative influence is rendered by poor control of public finances and high inflation, and protection of the intellectual property rights, the developed judicial system and other measures can render a positive effect.

Along with institutional factors education and labour improvement of professional skill, constant access to new knowledge and technologies can have crucial importance. The factors defining competitiveness of economy, differently influence economic systems of the countries of the world depending on starting conditions and a current level of development. Obviously, factors are change with time current. Researchers of this organisation use such approach for quantitative definition of comparative level of competitiveness of the concrete country, based on calculation of an index of global competitiveness. This technique was used to determine the strengths and weaknesses of the Russian economy, as well as the opportunities and threats in building competitive advantages.

\subsection{Sample}

Analysis of competitiveness of Russia is based on the WEF global competitiveness index 2006-2013. Reports are published annually by the WEF of countries rating which was based on the index of global competitiveness and the bratingsusiness competitiveness index. Studies are based on publicly available statistics and data on more than 11000 questioning business leaders in the analysed countries.

Global competitiveness index (GCI) proposed in 2004, by Professor Xavier Sala-I-Martin from the Columbia University (Xavier, 2004). For the characteristics of the competitiveness of the countries selected 12 sections: macroeconomic stability, infrastructure, health and primary education, higher education and training, goods market efficiency, labor market efficiency, technological readiness, development of the financial market, the size of the internal market, innovative potential and the quality of institutions.

All these sections include about 200 indicators affecting the business climate of countries. The global competitiveness index is a generalized assessment of competitiveness, based on an integrated approach.

\subsection{Instruments}

In order to develop ways to improve the competitiveness of Russia, we have provided answers to the following questions:

1) What competitive advantages of Russia currently possesses in relation to other States in the field of economy, politics, ecology, demography?

2) What disadvantages have Russia in the field of economy, politics, ecology, demography, which reduces its global competitiveness?

3) What resources are available to Russia to improve its competitiveness in the future 
4) What is threatens to increase level of global competitiveness of Russia?

5) What strategy for Russia is a priority in terms of use and build up a competitive advantage in the global economy?

\subsection{Findings}

Change in the global competitiveness index for Russia in 2006-2013 biennium. Shown in Figure 1. As you can see from the above chart, Russia moved down from 51 in 2008, at 64 in 2013. On the other hand, Russia has improved its position in the rating of competitiveness of world economies, rising from 67 to 64 . Such a jerk managed to do, mainly thanks to the good macroeconomic situation.

The low level of competition, a lack of confidence in the financial system and insufficient development of a business, on the other hand, pulled the country back.

The sharp improvement in terms of the macro-economic environment, Russia has moved from 44-th to 22nd place due to low government debt and because the budget has become a sufficient.

This, however, was not enough to offset the decline in ratings for its weak state institutes (133), the innovation potential of the economy (ranked 85 against 57 in the previous edition of GCI).

The country suffers from the low efficiency of the market for goods and services (134), labour (84) and the financial market (130-e), where the situation is deteriorating for the second year in a row.

The low level of competition (136), caused by the inefficiency of Antimonopoly Policy (124), high restrictions on trade and foreign ownership (of assets), as well as a lack of confidence in the financial system (134) contribute a lot to the inefficient allocation of enormous resources and hinders the improvement of productivity in the economy.

Business management and investment in condition of uncertainty contributes to development of financial infrastructure of the market economy.

She in Russia is developing rapidly, but is still weak compared with the leading countries.

Its underdevelopment impedes not only the assessment of the risk-return ratio and risk management through the purchase and sale of financial instruments.

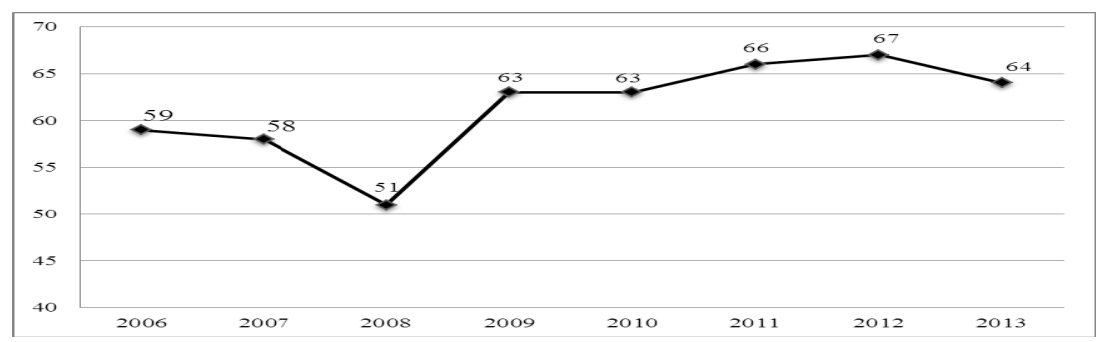

Figure 1. Change in the global competitiveness index in 2006-2013 biennium

Source: Based on data for the respective years: The Growth Competitiveness Index; The Global Competitiveness Report.

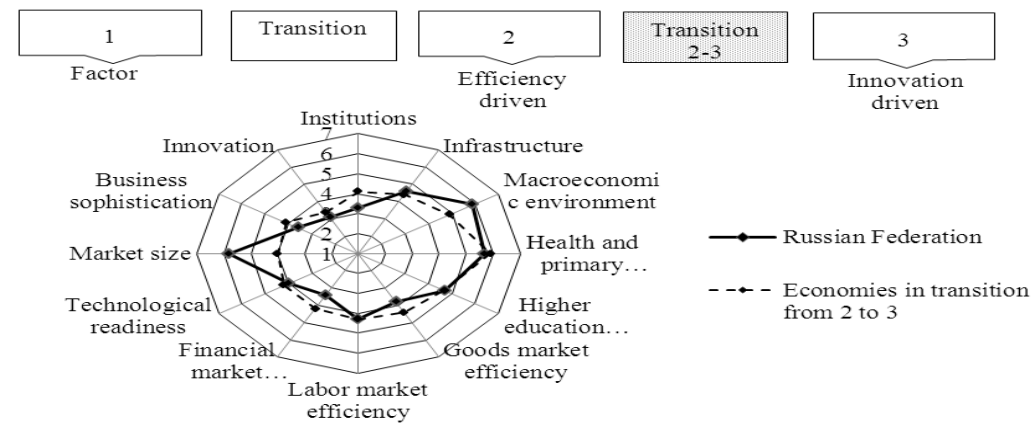

Figure 2. The diagram of factors of global index competitiveness according to the world economic forum for the 2013-2014

Source: The Global Competitiveness Report 2013-2014. 
It's hard to accelerate the development of this field. It requires a lot of specialists of high qualification, public confidence in the financial market, powerful and reliable means of control.

Moreover, as the country moves to a more advanced level of economic development, low levels of business development (119) and assimilation of technology (137) will become more and more important challenge for sustainable progress.

On the other hand, a high level of education, especially higher education, relatively good infrastructure and a large domestic market (7-e) represent areas that can be used to enhance the competitiveness of Russia.

\subsection{Discussion}

We have identified strengths, weaknesses, opportunities and threats in Russia to increase global competitiveness.

Strengths:

1) high prevalence of higher education;

2) a strong research base;

3) a significant amount of internal market;

4) the abundance of natural resources, including energy;

5) qualified personnel and high educational potential labour resources;

6) large area and geographical position of Russia;

7) capacity of internal consumer market.

Weaknesses:

8) the imperfection of the sectoral structure of the economy (industry, focused on the production and sale of consumer goods);

9) the high proportion of worn and obsolete equipment;

10) lack of education to business needs;

11) the high level of taxation;

12) not the effective system of salary charges and the distribution of incomes;

13) raw material export specialization;

14) ineffective pricing system (including energy costs);

15) the deficit developed transport infrastructure;

16) the big gap in economic development between regions (regions of donor and recipient regions);

17) a tiny funding of research.

Opportunities:

18) the ongoing processes of global economic integration;

19) further globalization of production relations;

20) development of productive ties with the countries of the former Soviet Republics (common economic space (CES) is a supranational economic community of the regional Customs Union, Belarus, Kazakhstan, Russia);

21) rising world energy prices;

22) high global demand for raw materials;

23) entry into the WTO.

Threats:

24) the flow of goods from China;

25) the unpredictable behavior of the Russian authorities, primarily law enforcement and tax authorities;

26) corruption of civil servants;

27) incompleteness of model of the functioning of the financial market, the stock market and banking sector (resulting in the banking and financial crises);

28) growth of tariffs of natural monopolies (gas, electricity, rail tariffs); 
29) political and economic uncertainty in the world and national systems;

30) Ukraine's accession to the European Union (the gap in industrial relations);

31) the world financial and economic crisis.

Based on the analysis of strengths, weaknesses, opportunities and threats, we have considered the following areas to improve the global competitiveness of Russia:

32) providing leading position of Russia's in the market of high technology, which requires a translation of the economy to the innovation way of development;

33) one of the conditions for improving the competitiveness of the world Russia and intensify mechanisms of public-private partnership is the development of regional industrial clusters of the type of industrial parks;

34) it is important to increase the competitiveness of the manufacturing and service sectors of the Russian economy through the effective use of customs tariff policy for the protection of domestic markets, such as special protective, anti-dumping and countervailing measures;

35) Russia has its own unique developments in the areas of aviation, rockets and space industries, opto-electronics, new materials, nuclear technology, geodetic equipment to search of oil fields and gas fields, software. The development of these areas, rather than buying public technologies would make it possible to reduce the technological gap;

36) must be ensure that the national interests of Russia in the international sphere, including non-discriminatory conditions of access of Russian goods, services and investments in foreign markets;

37 ) in the field of energy export routes diversification and expansion into new markets for energy carriers (hydrocarbon fuel), while maintaining sovereign control over energy resources;

38) determining factor for strengthening the position of Russia's geopolitical and geographical diversification of its foreign economic activity is the challenge of integration into the global transport system;

39) an important driver of growth in the global competitiveness of Russia is economic (in the direction of the development of industrial relations) integration with neighbors (both from the countries of former Soviet republics and China);

40 ) in the face of the global economic crisis must find new, effective methods for business development. One of the directions is the creation of special economic zones as designated areas to form the points of growth by attracting investments on concessional taxation and simplified conditions of opening and running a business. Through the development of specialization and outsourcing, optimize internal communication is improving the performance of cluster members, as well as the development of regional infrastructure (transport, information, educational, etc.). This eventually leads to maximize the competitive advantage of the Russian regions, allowing you to increase the welfare recipient regions.

\section{Conclusions}

The global competitiveness index due to its complexity and diversity is one of the few that can help assess the prospects of the development of the national economy. That certainly is an important factor for making predictions and creating effective national strategies.

The analysis showed, the peculiarities of national competitiveness (in particular, a significant amount of the domestic market, an abundance of raw resources, skills, etc.) have had a significant impact on the positive momentum of the international competitiveness of the Russian economy in the pre-crisis years, as well as the sharp fall in the competitiveness of the country in 2009-2010. The low competitiveness of Russia are such features as: the low level of development of the institutions of power, characterized by a high degree of bureaucracy and corruption, weak financial markets and low efficiency of goods market.

The methodology used in the writing of this article, has developed a reasonable strategy to raise the level of competitiveness in the face of instability in the world economy. It is based on the requirement of uniform improvement of basic factors of competitiveness of the country. Only the complex approach to this problem, the state stimulation and the account of the saved up experience in area of introduction of strategy of increase of competitiveness are capable to affect competitiveness of Russia at qualitative level and to promote its increase in sredne-and the long-term period.

\section{References}

Andrianov, V. (1998). Russia in the World Economy. Moscow: Vlados Humanitarian Center. 
Balassa, B. (1961). The Theory of Economic Integration. Homewood, Illinois: Richard D. Irwin.

Castells, M., \& Hall, P. (1994). Technopolies of the world. The making of $21^{\text {st }}$ century industrial complexes. London: Routledge.

Cooper, R. (2004). The Breaking of Nations: Order and Chaos in the $21^{\text {st }}$ Century. New York: Atlantic Monthly Press.

De Grauwe, P. (2013). Dimensions of Competitiveness. MIT Press.

Hajrullina, A. D., \& Romadanova, O. A. (2014). Technique of measurement of value of the human capital as intangible asset of corporation. Life Science Journal, 11(6s), 518-521.

Heckscher, E. (1919). The Effect of Foreign Trade on the Distribution of Income. Ekonomisk Tidskrift, 21, 497-512.

Heyne, P. (1973). The Economic Way of Thinking. Chicago: Science Research Associates.

Huggins, R., \& Izushi, H. (2011). Competition, Competitive Advantage, and Clusters: The Ideas of Michael Porter. Oxford University Press. http://dx.doi.org/10.1093/acprof:oso/9780199578030.001.0001

Jones, C. I. (1999). Growth with or without Scale Effects. American Economic Review, 89(2), 139-144. http://dx.doi.org/10.1257/aer.89.2.139

Kaufmann, D., \& Vishwanath, T. (2001). Toward Transparency: New Approaches and their Application to Financial Markets. World Bank Observer, 16(1).

Kirshin, I. A. (2014). Modeling the long-term trend of accumulation of knowledge. Life Science Journal, 11(6s), $482-486$.

Kramin, M. V., Safiullin, L. N., Kramin, T. V., \& Timiryasova, A. V. (2014). Drivers of economic growth and investment attractiveness of Russian regions. Life Science Journal, 11(6s), 526-530.

Krugman, P., \& Venables, A. J. (1995). Globalization and the inequality of nations. Quarterly Journal of Economics, 110(4), 857-880. http://dx.doi.org/10.2307/2946642

Lambin, J. J. (1996). Strategic Marketing Management. New York: McGraw-Hill Companies.

Miozz, M., \& Walsh, V. (2007). International Competitiveness and Technological Change. Oxford University Press.

Myrdal, G. (1957). Economic Theory and Underdeveloped Regions. London: Duckworth Publishing.

Noonan, C. (2008). The Emerging Principles of International Competition Law. Publisher: Oxford University Press. http://dx.doi.org/10.1093/acprof:oso/9780199207527.001.0001

Ohlin, B. (1933). Interregional and International Trade. Cambridge: Harvard University Press.

Porter, M. E. (1990). The competitive Advantage of Nation. New York: The Free Press.

Romer, P. M. (1990). Endogenous Technological Change. The Journal of Political Economy, 98(5), 71-102. http://dx.doi.org/10.1086/261725

Sachs, J., \& Warner, A. (1995). Economic Reform and the Process of Global Integration. Brookings Papers on Economic Activity, 1995(1, 25th Anniversary Issue), 1-118. http://dx.doi.org/10.2307/2534573

Safiullin, L. N., \& Novenkova, A. Z., Safiullin, N. Z., \& Ismagilova, G. N. (2014). Prospects of small business in Tatarstan. Life Science Journal, 11(6s), 396-399.

Safiullin, L. N., Gafurov, I. R., Shaidullin, R. N., \& Safiullin, N. Z. (2014). Socio-economic development of the region and its historical and cultural heritage. Life Science Journal, 11(6s), 400-404.

Sala-i-Martin, X. (2004-2005). The Global Competitiveness Index, The Global Competitiveness Report 2004-2005. World Economic Forum, Geneva, Switzerland, 51-80.

Stiglitz, J. E. (2003). Globalization and its Discontents. New York: W.W. Norton \& Co.

Validova, A. F. (2014). Inflation targeting in developing countries: Perspectives for Russia. Life Science Journal, $11(6 \mathrm{~s}), 494-498$.

\section{Copyrights}

Copyright for this article is retained by the author(s), with first publication rights granted to the journal.

This is an open-access article distributed under the terms and conditions of the Creative Commons Attribution license (http://creativecommons.org/licenses/by/3.0/). 